\title{
Antibacterial Activity Testing of Red Dragon Fruit Peel On Pseudomonas Sp.
}

\author{
Diah Setiani* \\ Nursing Departement, Poltekkes Kemenkes Kalimantan Timur, Indonesia. \\ *ners.diahsetiani@gmail.com
}

\begin{abstract}
Diabetic foot is a major consequence of neuropathy and peripheral vascular disease. Foot ulcers in diabetics increase the risk of amputation or even death. This study aims to determine the antibacterial activity of red dragon fruit peel against Pseudomonas Sp. bacteria that cause diabetic ulcers. This research was conducted using a completely randomized design (CRD) one factor, namely red dragon fruit peel with concentrations of $15 \%, 25 \%, 50 \%, 75 \%$, and $95 \%$, respectively. The positive control is amoxicillin and the negative control is sterile aquadest. The study began on August 12, 2019, until November 14, 2019, at the Laboratory of the TLM Health Polytechnic of Ministry of Health East Kalimantan. The data obtained were analyzed descriptively. The results showed the inhibitory concentration of Staphylococcus Aureus bacteria with the highest inhibition zone diameter was on the decoction of red dragon fruit peel with a concentration of $95 \%$, which is $16 \mathrm{~mm}$ (moderate inhibitory power). While the minimum inhibitory concentration is produced by a decoction of red dragon fruit peel with a concentration of $25 \%$ with a diameter of $9 \mathrm{~mm}$. The decoction of red dragon fruit peel with a concentration of 95\% has the highest inhibitory zone on the growth of Pseudomonas Sp. bacteria that cause diabetic ulcers compared to the dragon fruit peel with other concentrations.
\end{abstract}

Keywords: Antibacterial, Hylocereus Polyrhizus, Pseudomonas Sp, Diabetic Ulcer 


\section{STRADA Jurnal Ilmiah Kesehatan}

DOI: $10.30994 /$ sjik.v9i1.325

ISSN: 2252-3847 (print); 2614-350X (online)

Vol.9 No.1. May 2020. Page.303-309

\section{INTRODUCTION}

Diabetic foot is a major consequence of neuropathy and peripheral vascular disease, including infection of the lower limb, ulcer formation, and destruction of deep tissue. The incidence and prevalence of diabetic foot are 1.0-4.0\% and 5.3-10.5\%, respectively. About 20$30 \%$ of diabetic foot ulcers are located on the toes. Foot ulcers in diabetics are easy but difficult to cure due to several factors, such as thin subcutaneous fat and skin, slow blood flow, the resistance of large blood vessels, and hidden leg sutures. Foot ulcers also involve leg bones and thus increase the risk of amputation or even death (Ji, Bai, Sun, \& Wang, 2016).

Research in India, on 100 people with chronic diabetic ulcers, produced 82 positive cultures. Staphylococcus Aureus is a dominant organism, followed by Pseudomonas Aeruginosa (Banu, Noorul Hassan, Rajkumar, \& Srinivasa, 2015).

At Zainal Abidin Hospital showed that the most common type of bacteria found in consecutive diabetic pus ulcers was Staphylococcus Sp. (92.9\%), Klebsiella Sp. (75.4\%), Proteus Sp. (73.7\%), Shigella Sp. (68.4\%), Escherichia Coli Sp. (42.1\%), and Pseudomonas Sp. (10.5\%) (Nur, A dan Marissa, 2016).

One of the plants that are thought to have an antibacterial effect and are being consumed by many Indonesians is the red dragon fruit. Red dragon fruit is a fruit of the Cactaceae tribe, which is widely consumed in Indonesia. Red dragon fruit can periodically prevent and treat osteoporosis, hypertension, diabetes, and lower cholesterol (Warisno, 2010).

The purpose of this study was to determine the antibacterial activity of red dragon fruit peel against Pseudomonas Sp. causes of diabetic ulcers.

\section{METHODS \\ Research Design}

This research was conducted using a completely randomized design (CRD) one factor, namely red dragon fruit peel with concentrations of $15 \%, 25 \%, 50 \%, 75 \%$, and $95 \%$, respectively. The positive control is amoxicillin and the negative control is sterile aquadest.

\section{Population and Sample}

The population in this study were all red dragon fruit sold in the Samarinda Kedondong Market area.

The sampling technique was made by the consideration of researchers, by selecting old, ripe, and fresh fruit so that a sample of 1 red dragon was obtained.

\section{Procedure and Data Collection}

Red dragon fruit ingredients are collected and then cleaned. Before boiling, the pulp is separated from the peel and ground using a blender. Then filtering is done to get the red dragon fruit peel extract, after that it is done boiling over low heat for +5 minutes and made with a concentration of $15 \%, 25 \%, 50 \%, 75 \%$, and $95 \%$.

The test method used is disc diffusion (Kirby-Bauer). First, dip the sterile cotton swab into the $0.5 \mathrm{Mc}$ Farland standard bacterial suspension. Furthermore, the swab was evenly smeared on the MHA and left for 15 minutes so that the suspension of Pseudomonas Sp. seep into the MHA. 


\section{STRADA Jurnal Ilmiah Kesehatan}

DOI: $10.30994 /$ sjik.v9i1.325

ISSN: 2252-3847 (print); 2614-350X (online)

Then the MHA media was inserted paper disc with different concentrations, positive and negative controls were given a distance of $15 \mathrm{~mm}$ each, and incubated at $37^{\circ} \mathrm{C}$ for 24 hours.

Inhibition zone diameter measurements were carried out using a dark-colored base on MHA media and measured using a ruler/calipers. The diameter of the resistance zone measured is the clear zone around the paper disc, measured from one end to the other.

\section{Data Analysis}

The results of the antibacterial activity test in the form of inhibited zone diameters that have been measured are further presented in the table.

\section{RESULTS}

Table 1. Inhibition Zone Test Results for Pseudomonas Sp.

\begin{tabular}{cccl}
\hline & & $\begin{array}{l}\text { Inhibitory Zone } \\
\text { Diameter }(\mathbf{m m})\end{array}$ & \multicolumn{1}{c}{ Description } \\
\hline Red Dragon Fruit Peel & $15 \%$ & 10 & $\begin{array}{l}\text { Medium inhibitory } \\
\text { power } \\
\text { Medium inhibitory } \\
\text { power }\end{array}$ \\
& $25 \%$ & 9 & High inhibitory power \\
& $50 \%$ & 13 & High inhibitory power \\
& $75 \%$ & 13 & High inhibitory power \\
Control & $95 \%$ & 16 & $\begin{array}{l}\text { Medium inhibitory } \\
\text { power } \\
\end{array}$ \\
& $(+)$ & 9 & Low inhibitory power \\
\hline
\end{tabular}

Picture 1. Inhibition Zone Test Results for Pseudomonas Sp.

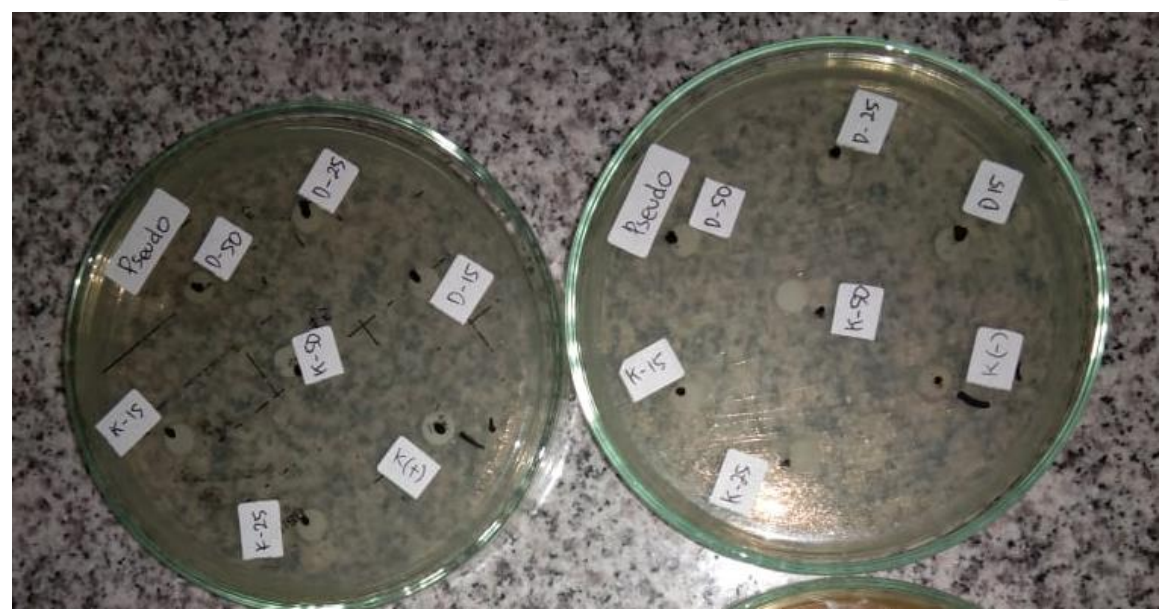

Table 1 shows the inhibitory concentrations of Pseudomonas Sp. with the highest inhibition zone diameter is the decoction of red dragon fruit peel with a concentration of $95 \%$, which is 


\section{STRADA Jurnal Ilmiah Kesehatan}

DOI: $10.30994 /$ sjik.v9i1.325

ISSN: 2252-3847 (print); 2614-350X (online)

Vol.9 No.1. May 2020. Page.303-309

$16 \mathrm{~mm}$ (moderate inhibition). While the minimum inhibitory concentration is produced by a decoction of red dragon fruit peel with a concentration of $25 \%$ with a diameter of $9 \mathrm{~mm}$.

\section{DISCUSSION}

The results showed that the inhibited zone formed had a diameter variation in each extract concentration and the decoction of red dragon fruit peel with a concentration of $95 \%$ had the highest inhibition zone against the growth of Pseudomonas Sp. compared to dragon fruit peel decoction with other concentrations.

Aurora (2011) research on the potential of red dragon fruit peel extract (Hylocereus Polyrhizus) as an antimicrobial compound shows that $10 \%$ of red dragon fruit peel extract can inhibit the growth of bacteria Pseudomonas Sp., Escherichia Coli, Staphylococcus Aureus, Bacillus Cereus (6.83-8.33 mm), but cannot inhibit the bacterium Penicillum Sp. and Mucor Sp. (Aurora, 2011). Research of Arum Anugrahati, Parhusip, Hardoko, \& Boing Sitanggang (2011) also showed antimicrobial activity with $10 \%$ extract of red dragon fruit peel (Hylocereus Polyrhizus) extracted using ethanol ethylacetate $80: 20$ at $26^{\circ} \mathrm{C}$ ) can inhibit the growth of gram bacteria positive (Staphylococcus Aureus and Bacillus Cereus) and gram-negative bacteria (Escherichia Coli and Pseudomonas Sp.) through inhibitory activity through damage to microbial cell walls indicated by intracellular concentrations of $\mathrm{Ca} 2+$ and $\mathrm{K}+$, each found as much as 13.09-15.16 mg/L and 567.96-797.52 mg/L (Arum Anugrahati et al., 2011).

This is in line with Shinta \& Hartono's research on the Antimicrobial Activity Test of Dragon Fruit Peel Extract against Escherichia Coli, Staphylococcus Aureus and Candida Albicans. That the results of the study indicate that the higher the concentration given, the greater the inhibitory zone formed. The highest inhibitory power of dragon fruit peel extract against Escherichia Coli at the highest dose of 2 grams was $10.33 \mathrm{~mm}$. The highest inhibitory power of dragon fruit peel extract against Staphylococcus Aureus at the highest dose was 2 grams, a mean of $8.66 \mathrm{~mm}$. The highest inhibitory power of dragon fruit peel extract against Candida Albicans at the highest dose of 2 grams averaged $7.66 \mathrm{~mm}$ (Shinta \& Hartono, 2018).

Other research results on the Antibacterial Activity of Red Dragon Fruit Ethanol Peel Extract (Hylocereus Polyrhizus) against Streptococcus Pyogenes bacteria by Suhartati \& Roziqin (2017) which shows the red dragon fruit peel can inhibit the growth of Streptococcus Pyogenes bacteria. Inhibition zone at a concentration of $10 \%$ is $6 \mathrm{~mm}$, the concentration of $20 \%$ $6.5 \mathrm{~mm}$, the concentration of $40 \% 8 \mathrm{~mm}$, the concentration of $60 \% 9 \mathrm{~mm}$, and the largest zone is produced at concentrations of $80 \%$ and $100 \%$ that is equal to $12 \mathrm{~mm}$. Positive control of penicillin produces zones of $22 \mathrm{~mm}$ while negative controls do not produce inhibitory zones. The results of the Minimum Kill Concentration (KBM) test found at a concentration of 100\% can kill the growth of Streptococcus Pyogenes bacteria (Suhartati \& Roziqin, 2017).

Researchers assume that the content of flavonoids and alkaloids is what makes a major contribution in inhibiting the growth and development of Pseudomonas Sp. bacteria.

Red dragon fruit peel contains several active compounds, namely alkaloids, terpenoids, flavonoids, thiamine, niacin, pyridoxine, cobalamin, phenolic, carotene, and phytoalbumin (Jaafar, Abdul Rahman, Mahmod, \& Vasudevan, 2009). Red dragon fruit peel extract contains 


\section{STRADA Jurnal Ilmiah Kesehatan}

DOI: $10.30994 /$ sjik.v9i1.325

antioxidants in the form of vitamin C, flavonoids, tannins, alkaloids, steroids, and saponins based on the results of photochemical and FTIR tests (Noor, Yufita, \& Zulfalina, 2016).

Research by Sartika, Sutikno, Yuliana, \& M (2019) shows that the red dragon fruit peel is dominated by ascorbic acid 2,6-dihexadecanoic (26.56\%), oleic acid (24.08\%), estra1.3.4 (10 ) trien-17 beta-ol (9.63\%), 9,12-okta acid dienoik (Z, Z) (8.27\%), and organic acids, phenols, flavonoids, esters (31.46\%) which potential as a natural anti-microbial (Sartika et al., 2019).

Flavonoid compounds as anti-microbial have 3 mechanisms of action namely inhibiting nucleic acid synthesis, inhibiting cell membrane function, and inhibiting energy metabolism (Hendra, Ahmad, Sukari, Shukor, \& Oskoueian, 2011). The antibacterial mechanism of flavonoids in inhibiting the synthesis of nucleic acids is the rings A and B which play an important role in the process of interconnection or hydrogen bonding by accumulating nucleic acid bases that inhibit the formation of DNA and RNA. The location of hydroxyl groups in positions 2 ', 4' or 2 ', 6' is hydroxylated in ring B and 5.7 hydroxylated in ring A plays an important role in the antibacterial activity of flavonoids. Flavonoids cause damage to the permeability of bacterial cell walls, microsomes, and lysosomes as a result of interactions between flavonoids and bacterial DNA (Cushnie \& Lamb, 2005).

The mechanism of action of flavonoids inhibits the function of cell membranes by forming complex compounds with extracellular and dissolved proteins that can damage bacterial cell membranes and is followed by the release of intracellular compounds. Other studies suggest that the mechanism of flavonoids inhibits the function of cell membranes by interfering with the permeability of cell membranes and inhibiting the binding of enzymes such as ATPase and (Li, Wang, \& Liu, 2003). Furthermore, flavonoids can inhibit energy metabolism by inhibiting the use of oxygen by bacteria. Flavonoids inhibit cytochrome $\mathrm{C}$ reductase so that metabolic formation is inhibited. Energy is needed by bacteria for macromolecular biosynthesis (Cushnie \& Lamb, 2005).

In addition to flavonoids, alkaloids have pharmacological effects on humans and animals as antibacterial substances. This is because alkaloids can inhibit the work of enzymes to synthesize bacterial proteins. Inhibition of the work of this enzyme can result in impaired bacterial metabolism (Ogbuagu, 2008).

\section{CONCLUSION}

Based on the results of this study concluded that the decoction of red dragon fruit peel with a concentration of $95 \%$ has the highest inhibitory zone on the growth of the bacterium Pseudomonas Sp. causes of diabetic ulcers compared to the decoction of dragon fruit peels with other concentrations.

\section{ACKNOWLEDGEMENT}

We highly appreciate the parties supporting this research, the Health Polytechnic of the Ministry of Health, East Kalimantan, especially the Department of Nursing and Medical Laboratory Technology. 


\section{STRADA Jurnal Ilmiah Kesehatan}

DOI: $10.30994 /$ sjik.v9i1.325

ISSN: 2252-3847 (print); 2614-350X (online)

Vol.9 No.1. May 2020. Page.303-309

\section{REFERENCES}

Arum Anugrahati, N., Parhusip, A. J. N., Hardoko, \& Boing Sitanggang, A. (2011). Karakterisasi Aktivitas Antioksidan dan Antibakteri dari Kulit Buah Naga Merah. Tangerang.

Aurora, T. (2011). Potensi ekstrak kulit buah naga merah (Hylocereus polyrhizus) sebagai senyawa antimikroba.

Banu, A., Noorul Hassan, M. M., Rajkumar, J., \& Srinivasa, S. (2015). Spectrum of bacteria associated with diabetic foot ulcer and biofilm formation: A prospective study. Australasian Medical Journal. https://doi.org/10.4066/AMJ.2015.2422

Cushnie, T. P. T., \& Lamb, A. J. (2005). Antimicrobial activity of flavonoids. International Journal of Antimicrobial Agents. https://doi.org/10.1016/j.ijantimicag.2005.09.002

Hendra, R., Ahmad, S., Sukari, A., Shukor, M. Y., \& Oskoueian, E. (2011). Flavonoid analyses and antimicrobial activity of various parts of Phaleria macrocarpa (Scheff.) Boerl fruit. International Journal of Molecular Sciences. https://doi.org/10.3390/ijms12063422

Jaafar, R. A., Abdul Rahman, A. R. Bin, Mahmod, N. Z. C., \& Vasudevan, R. (2009). Proximate analysis of dragon fruit (Hylecereus polyhizus). American Journal of Applied Sciences. https://doi.org/10.3844/ajassp.2009.1341.1346

Ji, L., Bai, J. jiao, Sun, J., \& Wang, Z. (2016). Nursing care for diabetic toe ulcers: A case series report and literature review. International Journal of Nursing Sciences. https://doi.org/10.1016/j.ijnss.2016.04.007

Li, H., Wang, Z., \& Liu, Y. (2003). Review in the studies on tannins activity of cancer prevention and anticancer. Zhong Yao Cai = Zhongyaocai = Journal of Chinese Medicinal Materials.

Noor, M. I., Yufita, E., \& Zulfalina. (2016). Identifikasi kandungan ekstrak kulit buah naga merah menggunakan faurier transform infrared (ftir) dan fitokimia. Journal of Aceh Physics Society (JAcPS).

Nur, A dan Marissa, N. (2016). Gambaran Bakteri Ulkus Diabetikum di Rumah Sakit Zainal Abidin dan Meuraxa Tahun 2015. Buletin Penelitian Kesehatan, 44(3), 187-196.

Ogbuagu, M. N. (2008). The nutritive and anti-nutritive compositions of calabash (crescentia cujete) fruit pulp. Journal of Animal and Veterinary Advances.

Sartika, D., Sutikno, S., Yuliana, N., \& M, S. R. (2019). IDENTIFIKASI SENYAWA ANTIMIKROBA ALAMI PANGAN PADA EKSTRAK KULIT BUAH NAGA MERAH DENGAN MENGGUNAKAN GC-MS [Identification of Food Natural Antimicrobe Compound from Red Dragon Fruit Peel Extract by GC-MS]. Jurnal Teknologi \& Industri Hasil Pertanian. https://doi.org/10.23960/jtihp.v24i2.66-76

Shinta, D. Y., \& Hartono, A. (2018). UJI AKTIVITAS ANTIMIKROBA EKSTRAK KULIT BUAH NAGA (Hylocareus costarisensis) TERHADAP E.coli, Staphylococcus aureus, DAN Candida albicans. Sainstek: Jurnal Sains Dan Teknologi. https://doi.org/10.31958/js.v9i1.602

Suhartati, R., \& Roziqin, D. A. (2017). Aktivitas Antibakteri Ekstrak Etanol Kulit Buah Naga Merah (Hylocereus polyrhizus) Terhadap Bakteri Streptococcus pyogenes. Jurnal Kesehatan Bakti Tunas Husada, 17(2), 513-518. 


\section{STRADA Jurnal Ilmiah Kesehatan}

DOI: $10.30994 /$ sjik.v9i1.325

ISSN: 2252-3847 (print); 2614-350X (online)

Vol.9 No.1. May 2020. Page.303-309

Warisno, D. K. (2010). Cara Pintar Bertanaman Buah Naga di Kebun, Pekarangan dan dalam Pot. Jakarta: Gramedia Pustaka Utama. 